\title{
Philosophical - Psychological 's Recognition of Concept of Spirituality
}

\author{
Maryam Solgi ${ }^{1}$, Maryam Safara ${ }^{2 *}$ \\ 1\&2Women Research Center, Department of Psychology, Alzahra University, Tehran, Iran
}

Corresponding Author: Maryam Safara, E-mail: m.safara@alzahra.ac.ir, safara_maryam@yahoo.com

\section{ARTICLE INFO}

Article history

Received: December 06, 2017

Accepted: March 04, 2018

Published: April 30, 2018

Volume: 9 Issue: 2

Advance access: March 2018

Conflicts of interest: None

Funding: None

Key words:

Spirituality,

Spiritual,

Human,

Transcendental Act.

Religion.

\begin{abstract}
In many of the contemporary writings, the scholars have talked about spirituality as a constant pursuit of humanity throughout history. Throughout history, the search for spirituality has found numerous cultural interpretations, but its critical and comparative study in the global and intercultural context is an emerging phenomenon of the twentieth century.Although many contemporary dictionaries and encyclopedias refer to spiritualism, spiritual associations, and spiritual experiences, or spiritual ways, they are not necessarily included an entry for spirituality in the true sense of the word.Some religions do not have a precise word for the term 'spirituality' which derives from the Christian tradition, but nevertheless the notion of spirituality has become popular today and is now used both inside and outside the religions as well as in the inter-faith and secular fields. The tendencies that are common in contemporary times to spirituality emphasize individuality and self-development and have been accompanied by a different understanding of human psychology.
\end{abstract}

\section{INTRODUCTION}

Today, spirituality has become a keyword which indicates the search for meaning and direction, and in modern society, it is a lost phenomenon in the materialist world. It seems such that in the contemporary secular society, humanity seeks to reestablish spirituality as a lost paradise hidden from the material world. This process has been made easier by examining the many traditional works that widely exist in various religious traditions (Hinliss, 2003: 225). In order to understand spirituality in a broad intercultural context, one must precisely understand what is the concept of spirituality?

For this reason, in this essay, before the etymology and definition of spirituality, at first, the terminology of this term is discussed in the Christian tradition, in the cultural-intellectual paradigm of the West and in the Persian language and literature, and then the conceptual analysis of "spirituality" will be addressed, that is, what less has been discussed in the writings related to spirituality.

The purpose of this article is the philosophical-psychological recognition of the concept of spirituality in English and Persian literature, in this way, by clarifying the concept of spirituality, the way to agree on the recognition of this concept is to prevent many of the problems caused by conceptual ambiguity in this issue and pave the way for further research in other disciplines of the humanities on this issue

\section{A LOOK AT THE TERM "SPIRITUALITY" IN THE WESTERN CULTURAL-INTELLECTUAL PARADIGM}

The term spirituality has been used very vaguely over the past few decades, and the origin of the use of this term in the European languages is entirely new, that is to say, in the last few centuries, the term was used for the first time in Catholic rhetoric.

The Catholic Encyclopedia, published before the First World War, did not mention spirituality, while the new Catholic Encyclopedia, published in the 1970s, has eight entries on different aspects of this subject. In authoritative reference books, such as Oxford Dictionary and Webster's International Dictionary, a definition of spirituality has been introduced as a religious inquiry area. In the Encyclopedia of Religion, the terms such as spiritual discipline, spiritual guide, and Christian spirituality have been introduced, but the term spirituality itself has not been independently discussed (Eliade, 1981: 29). In the encyclopedia of the World Book, spirituality has not been independently discussed, although there 
are also entries in the book about spiritual attributes and spiritualism (The Encyclopaedia of the Word Book, 1960: 620).

In the Colombian encyclopedia, the exact same thing is repeated, that is, there is no independent discussion of spirituality, but there are also discussions about the spiritual trait and spiritualism (Water, Sherwood, \& Elizabeth, 1963: 2020).In the new Catholic encyclopedia, as mentioned and we will discuss it later in this article, as well as the Protestant encyclopedia, there are independent entries on spirituality (Brand, Joachim, 2004: 1800).

But due to the fact that an intra-religious and completely Christian context has been discussed there, it seems that there is little difference between it and the encyclopedia of religion in which Mircea Eliadehas added an article about Christian spirituality and not a free and unconditional spirituality. This issue, even to some extent, can be attributed to the Encyclopedia of Religion and Ethics.

After this brief bibliography report in the reference books about "spirituality" and the terminology and definitions of the term in the dictionaries and encyclopedias, it is now worthwhile that to deal with semantic discussions and definitions of the term.

\section{TERMINOLOGY OF "SPIRITUALITY"}

Spirituality derives from the Latin word spirare and spiritus which mean 'soul', 'vital principle' and 'breath'(Ragan, 2000) that in medieval Latin it is called spiritulit that is the English equivalent of 'spirit' which means the soul, and is also equivalent to the Greek word pneuma and the French word esprit and the German word gist (Maher \& Bolland, 1907: 226)which means part of the body that is not physical (Clarend, 1993: 2990; The Heritage Illustrated Dictionary of the English Language: 1251). All these names are the titles that indicate the origin and source of life, and often these names are categorized under the infinitive 'to breathe', the thing which is the visible sign of the life and the disruption of that is a visible constant sign of death.

In psychology, the word 'spirit' is used as the adjective 'spiritual' to show and characterize everything that relates to a life more superior than reason (art, morality and religion) in contrast with a life that is merely related to the sense perception, senses, material and related rules. The use of the word 'spirit' is also different in verbal statements. In the New Testament, this word is sometimes used equal to human soul and sometimes equal to divine meta-physical acts in human, and sometimes equal to Holy Ghost (the true spirit which can not understand by the universe).

Such use of this term implies a supernatural divine life that was expounded by St. Paul, in which the material is generally considered as a limiting sense of the soul, and finite spirits are limited by the need for a person's body and the only infinite spirit is God who is free from any material combination (Maher \& Bolland, 1907, vol.14: 226).

Another point to be noted is that the term 'spirit' is similar to the words such as 'inspire' and 'abandon' (Exploring the meaning of spirituality: www.DUMMIES.com), and this is specific to the times you are full of spiritual energy; because you feel a great inspiration within yourself and the spiritual life also forces people to abandon their material body (Pace, 1907; Bolland, 1907). Spiritualism is the term is often used to convey the belief that ghosts are associated with bodies after being separated from them. However, the term 'spiritism', which is used in German, French, and Italian languages, seems to be more appropriate for this meaning (Catholic Encyclopedia, 229).

Spiritualism is a doctrine that denies the reality of material substance and material properties, and advocates the true creatures that, in this doctrine, are the minds and spirits and essentially distinct from material substances. Spiritualism can take the form of spiritual idealism that either refuses to exist any true material entity outside the world of the mind or that accepts an independent existence for the material world, and at the same time, defends the existing spiritual truth. Spiritualism can also take on other forms that are not discussed here (Ibid, 229).

Now that the meaning of the 'spirit' as the root of the term 'spirituality' has been clarified, it is necessary to study the term 'spirituality'.

\section{THE CONCEPT OF SPIRITUALITY}

The term 'spirituality' has been used in a great variety of ways; for example, the French has appropriated it as the name for 'finer perceptions of life' and by American transcendentalists it is used as a special mark of superior intellects. The concept of spirituality was a novel-Catholic term until the end of the $19^{\text {th }}$ century, and its concept was to livewhen communicating with God through the Holy Spirit (Hasting, in Encyclopedia of Religion: 808). This term was gradually reversed to describe the concept that the spirituality of life is based on the evolution of the soul and not the common experience of all Christians (Spohn, www.Relg-studies.scuedu).

The Protestant Christians also use this term to describe the warmer religious emotions and it has its proper and peculiar application as the distinguishing quality of NT believers (New Testament). Spirituality does not occur in Scripture, but the adjective 'spiritual' is frequently employed to describe the specific character of the man who has entered the "kingdom of God". Such a man has the Holy Spirit as the vital determining principle of his life. NT movement does not permit us to apply the epithet to any one who has been moved with some vague way by holy impulses, because in this doctrine a specific attribute is indicated by virtue of this description (Hasting, in Encyclopedia of Religion: 808).

The definitions of the term 'spirituality' in different dictionaries are as follows:

1. The state or manner of being spiritual; non-material. The worldly affaires are the opposite of the spiritual affaires; the mindedness and heavenly soul; pleasure deserves the spiritual soul (The American Heritage Dictionary); a great amount of comfort and spiritual state that is achieved in general worship depends to the state occurs for the soul (The American Heritage Dictionary; Oxford English Dictionary, 2003: 2290).

2. Clergy (Bossley Woolf, in Webster's New Collegiate Dictionary: 1122).

3. Something that in ecclesiastical law belongs to the 
church or a cleric as such; the real property of the church (Word net 2.0, 2003: www.dictioary.com).

4. What belongs to the church, priest, or religion, other than worldly possessions; the outpost of the covenant; therefore, the bishop is a protector of spirituality (spirituality: http://www.helpyourself.com).

5. Relationship with spiritual, sacred and supernatural matters (such as church, religion, God) (Bossley Woolf, in Webster's New Collegiate Dictionary: 1122).

6. The reality of non-material existence, the affair related to its essence, a subtle state or quality, and emotions related to the soul (Nafisi, 1939, vol. 5: 3416).

7. The priest's body; the body of all the clerics is as an entity which id distinct and contrary to bodily integrity (Ibid, 1122).

According to the above passages, almost what is common about the literal definition of this term in all dictionaries is the same spiritual state of soul and relationship with spirit, the abstract affaires and the sacred and supernatural subjects. According to the agreement of these dictionaries about definition of spirituality, it seems that we must select the same literal definition for the term.

\section{CONCEPTUALIZATION OF "SPIRITUALITY" IN PERSIAN LANGUAGE AND LITERATURE}

The word spirituality [Ma'naviyyat in the Persian] is derived from the word $M a$ 'ni, i.e. meaning, and in Persian the term Ma'ni is derived from Arabic (Nafisi, 1939: 3416); in Pahlavi dictionary; 1.Mānak, Mānāk, Zand, Ersh (logical reason);

2. Jam (solid body), Mafhūm (concept) (Partou, 1988: 1105); the term Ma'ni is a locative case which denotes the place from the infinitive 'Ināyat meaning intention and will or the object noun from the same infinitive which means what is asked by the term and figuratively mean the work must be done (Daei al-Islam, 1985: 184). It means the intention, the signified and the concept implied, contents, interpretation and paraphrase versus the word (Deh Khoda, 1973: 761; Amid, 1997:1105; Beheshti, n.d.: 1022); in public culture, it means having some intention, being deserved and having an aspect (Najafi, 1999: 1357). In Ghiyyāth al-Lughāt [a Persian reference book], we read: The term $M a$ 'ni has originally been Ma'noviin the rhythm of Maf' $\bar{l} l$ [in Persian].

Ma'navi (spiritual): Ma'naviis the Arabized Persian word of Mīnoviand the Pahlavi word Mīnovic, Vaxshāk, Mānkī, Mānākī (Partou, 1988: 1890); Ma'navi means something related to meaning; 1. inner, true, spiritual, mental; 2. Gnostic; 3. Spiritual versus apparent, formal and verbal, as well as the meaning that is only understandable by heart and cannot be stated by language (Khodaparasti, 1997: 408); the true man who understands the inner meaning; Masnavi Ma'navi [the book by Mawlānā] is the couplet-poems which include true meaning and reality (Alavi, 1996: 561). In the following distiches, Ma'navi (spiritual) has been used in the above-mentioned meanings.

"Listen to spiritual advices by your mind ear

Be careful what is said, think of it and remember

(Nasser Khosrow)

Word is worthwhile because of its meaning
Spiritual should be,Arabic or Persian saying (Adib Saberi)

How can speak on the behalf of you at all

If so, noting must be said except spiritual

(Attar)

The reasons must be strong and spiritual as well

No strong reason no acceptable if be neck vessel

(Saadi)

One must sacrifice his soul to know scarified soul

The bride of the meanings needs two eyes spiritual (Molavi)

I am a judge, not the spiritual man

My spirituality is from the cloak I keep it as I can

(Attar)

Nightingale sings Pahlavi song over a cedar branch

Read the lesson of spiritual steps last night as much

(Hafez) (Deh Khoda,

1973: 764).

Ma'naviyyeh (feminine of Ma'navi in Arabic) [i.e. spirituality]; the world of meaning; the inner world, the spiritual world and the unseen.

Ma'naviyyeh (Spirituality): This is the arabized equivalent of the Persian word "Minov $\vec{\imath}$ " meaning to be spiritual (which was described previously) (Partou, 1988: 1889). Therefore, the term Ma'naviyyeh in Persian, as spirituality in English, refers to "religious affairs versus formal and apparent affairs". Now, after etymology of the term, we define the meaning and definition of the term "spirituality".

\section{FINDING THE MEANING AND DEFINITION OF SPIRITUALITY}

The issue of spirituality, as already mentioned, has been a concern for humanity throughout its history on the earth; in general, efforts have been made to define spirituality by going beyond the presuppositions of religious affairs, but the opinions related to this process are different (Schlodark, 2001: 243).

And basically, since the term used in a variety of fields and, in particular,vaguely over the last few decades, it has been too difficult to define. Several definitions of spirituality have been introduced, but in various definitions, there are some key points that Mitroff and Elizabeth Deton in a research on "spirituality at work" refer to as follows:

The definitions of spirituality are not often organized, formal, and structured, they usually include an element of sacredness, an infinite source of faith and will power, as well as an ultimate end; they are non-sectarian, go beyond the creeds and are universal, and non-dimensional and timeless. In addition, transcendental existential presence, deep feeling of interconnectedness with everything and inner peace and calm are some elements that are commonly found in the definitions of spirituality (Mitroff, Denton, \&Elizabeth, www. workplacespirituality.com). In many contemporary writings, spirituality has been mentioned, but since this term has been used in very different fields, it is not easy to define it; Evelyn Underhill in the book of The Spiritual Life, about the sensitivity of the definition of spirituality says: In human language, there is not a word to be right and proper about the realities 
of spirituality, therefore, we must be careful about two things: One is to avoid hasty definitions, and secondly, to prevent ambiguity and over-abstraction (McCormick, 2004: 108).

Some, like Underhill, consider the indescribability of spirituality is an obstacle to define it, while others have tried to define spirituality in detail. Today spirituality has various aspects that cover different tendencies. Once, spirituality was considered as a part of religion. Today, some people consider spirituality as the heart of religion and its highest ideals that face it especially in the religious and mystical experience (King, 2004: 80).But some see religion as one of the possible spiritual paths and prefer spiritual belief to religious belief, because they believe that spirituality is less institutionalized and more extensive. Once, spirituality was a way for deep connection with God; today, for many, God is no longer the sole purpose of their spiritual searches, but it can be one of the possible ways of spiritual search. Bowman recounts the ideas of Underhill from a postmodern perspective and states that the definitions of terms such as spirituality are hiding as much as they are enlightening. While she wants to explain more and more, makes the subject more complicated and says that if we fail to provide a rational definition we will enter the postmodern world and we will not reasonably ready for this research (McCormick, 2004: 180; Mitroff, Denton, \& Elizabeth, ibid).

Spirituality has also been defined in a way in which a person finds his own historical context and lives in. This is a manifestation of religion, philosophy, or ethics, which is shown as the highest, most accurate and measured thing, and results in the richness of an ideal or desirable perfection. In a relatively comprehensive definition, spirituality is considered as an attempt to become sensitive to self, others, non-human beings and God, or finding what is needed for mankind and trying to achieve complete humanity (King, 2004: 75). Spirituality is an obscure term that, for many people, means some kind of mysterious and tedious activity (Wickfield, 2002: 65).

Everet Cousins, in the introduction to the important collection of World Spirituality: History of the Religion Quest, describes spirituality as the inner movements of the soul, which addresses a transcendent reality. It is necessary to note that although spirituality is the same as the general search of human beings, the often close relationship between religion and spirituality must be understood (King, 2004: 75).

Definitions of this kind that consider spirituality as an aspect of individual and social life that expresses the person's conscious relationship with the "transcendent" (Troll, 1995: 165) or that a divine light within the human being is supposed without which, as desire or breath, we cannot live. And also, the definitions that indicate that spirituality connects man with the divine power that exists in the existence (Exploring the meaning of spirituality; ibid), as well as those definitions that consider the main meaning of spirituality as the confirmation of the spirit or God in the hearts (souls) of all human beings (Ragan, ibid) essentially involve a presumption, and that is, the transcendent fact exists and the soul can communicate with it. The materialist approach, which basically relies on empirical reasons and is based on the five senses, according to these definitions, deny the ex- istence of an example for spirituality. It is nevertheless possible that those who are not associated with any organized religion may communicate with an absolute fact, whether it is known as personal God or not. For this reason, we can talk about the spirituality of individuals or groups of people who live outside the structures of organized religions, i.e., it is theoretically possible that someone is spiritual, and his/ her spirituality is associated with the transcendental reality (absolute fact) and at the same time s/he does not believe in one of the historical religions of the world, but the fact is that during the history, most of those people who have been spiritual have belonged to one of the institutional and historical religions, but The definition of spirituality in a universal and general way, which seeks for what is associated with humanization, is an impartial definition, which does not refer to religion in the true sense of the word. This definition emphasizes on spirituality as a dynamic power in human life (King, 2004: 75).Here we can use the term used by Pual Telch who believes the spirituality of a person is the manifestation of his/her ultimate faith which means something that is considered much valuable and sacred by that person (Griffin, 2002: 241).

Definition of spirituality in an inter-faith sphere dependent on the essence and the core of religion and the inner dimension of religions is also contemplative, in which the spiritual affairs are directly experienced and are beyond the subjective affairs, but not anti-rational. On the contrary, if reason is understood in its original sense and not in its argumentative one, then spirituality and rationality are inseparable (Nasr, 1999: 77). In this case, the possibility to achieve spirituality is denied for all those who merely belong to a religion based on the tradition of the family.

\section{WHAT IS TRUE SPIRITUALITY?}

It seems necessary to emphasize the point that spirituality can never be anti-rational, although it may not be included in and goes farther in some frameworks. Basically, the definitions of spirituality are very similar to the definitions of reason since they are beyond the senses and cannot be included in the framework of physical affaires. We cannot have non-rational or anti-rational spirituality (Ibrahimi Dinani, 2003: 11), but in contrary, spirituality and rationality are constantly interconnected, and are gathered. We theoretically consider rationality to discover values, realities and tasks, but in practice we need spirituality which is an inner action; that is, after discovering and receiving beliefs we need an inner factor called spirituality (Malekian, 2000: 69).

Traditionalists, such as Schuon, who think completely in a religious space, consider spiritual experience as one type of worship. Schuon believes that every person at the spiritual level needs truth, morals and spiritual experience; the pure and obvious truth is consistent with the metaphysics, and the pure metaphysics is in every religion, and morality is also a dimension of spiritual life, which means a sensible, healthy and polite behavior. He knows the worship as three parts: religious worship, individual worship and thankful worship and considers the part three as the mystic spirituality which can be the same religious experience (Schuon, 1992). In some defini- 
tions in the Christian tradition, spirituality and worship have precisely been considered the same (Wickfield, 2002: 65). Indeed, in these views, spirituality is the gist and essence of worship. In this traditionalist view, spirituality is equivalent to religion. Religion in its original sense is the same principles which have been inspired from the heaven, linking man to his origin. This spirituality is the relation and presence that is connected to the holy and inner fact as well as spiritual life. This spirituality is obtained from tradition. In this view, spirituality is the source of divinity that seethes, dances and flows as the essence of every soul. Here, spirituality is the mystical form of religion, and it explains the human's search for discovering his larger meaning and his existential purpose. Some of the principles of this spirituality are as follows:

1. Look beyond the apparent face

2. Love, respect and bow to God

3. Love and respect to human beings (Exploring the meaning of spirituality; ibid).

In the Encyclopedia of Religion and Ethics, spirituality is defined as a secret and confidential state which is the certain and legal result of the life that was portrayed by Jesus. "Our Lord Jesus, wherever he went, offered a sacred and beneficial life that he could achieve from unity with himself". Spirituality is the main characteristic of Jesus' proposed life, and clearly it is his demand. It is written in the Bible: "Ye must be born again" (Hastings, in Encyclopedia of Religion and Ethics: 808).

In all of these sentences it is seen that religion and spirituality are beautifully combined and despite the fact that the external manifestations of religions are very different, their essence and nature is spirituality. Some have gone so far as to proclaim the essence of spirituality is God or the transcendent entity (Exploring the meaning of spirituality; ibid).Interestingly, almost the same issue can be seen in Mawlana's thoughts, where he says:

The meaning of the Sheikh of the religion is Allah, he said An ocean of meanings of the Lord of the heaven and world The stories of the earth and the sky

Float on that ocean like a sting by (Mawlavi, 1996, vol. 1: 148).

Some believe that Mowlana's intention of "Sheikh Din" [Sheikh of the religion] has been Sadr al-Din Qunavi, and some believe that he means Muhi al-Din Ibn Arabi, but some of the researchers in our day have said that probably he his intention of the "Sheikh Din" have been his father who said: "We are the gods"; because there is not such a statement in any of the books of Ibn Arabi and Sadr al-Din Qunavi. Although some also believe that Sadr al-Din Qunavi, in his own words, mentioned these sentences and Mawlana speaks of his tongue, but there are many ideas on the interpretation of "the meaning of the Sheikh of the religion is Allah". If his intention is 'Allah', so theology is equal to semiotics and to pay attention to God is to pay attention to meaning and to think about God is to think about meaning. In this respect, theology can be regarded as the knowledge of spiritual affairs and the respect of spirituality, and humility and yield to God. Here, "the meaning" refers to the fact beyond the veil of the face; everyone who can pass through the difference of faces that appear in the universe of appearance and reach to the unified meaning hidden beyond the apparent face is complete, that is, s/he has achieved to perfection. Here the intention of "the meaning" is single, simple and eternal truth, which is hidden from being seen and is condemned to destruction in the face of appearance, and Mowlana refers to contradiction of these two worlds, where he says:"so what is "the meaning" of a form, except humbleness? Or wherever he says; "by which the form of appearance is destructed// the world of meaning will remain eternal indeed" (Mawlavi, 1996, vol. 2: 215). The prophets and apostles are the messengers of the world of meaning. These sentences can interpret some aspects of the message contained in the phrase "the meaning of the Sheikh of the religion is Allah" (Movahed, 1995: 6).

Spirituality in this sense goes beyond all sciences, philosophies and religions (Exploring the meaning of spirituality; ibid).

In this spirituality, the reality is both transcendental and beyond time and space, and physical domain and is higher than any conceptualization of the mind, but at the same time it dominates all of these realms; it cannot be understood, meaning that, it cannot be encompassed because no onecan understand any infinite fact. At the same time, the infinite fact can be recognized with reason, as one of the divine epistemic powers in the center of existence; this fact is absolute, ultimate, and infinite; it is the origin of all virtues. This spirituality is always aware of the distinction between the source and its manifestations, i.e., among Atman ${ }^{1}$ and Maya ${ }^{2}$, Nirvana $^{3}$, Samsara $^{4}$ of divine essence and the veils that cover the manifestation of the divine names and attributes. This spirituality, in which the absolute reality is addressed as an unmistakable fact, is based on the assertion that reality not only has steps, but also awareness of it has hierarchies and what we see (of course, not visual and sensory seeing) depends on our knowledge and consciousness, and the type of our knowledge and consciousness depends on the nature of our existence, and what changes our nature of existence and consciousness is our spiritual discipline. Such knowledge has always been the internal source of life and the vital force of morality in various religions.

But in today's modern world, where there is a denial of the soul and the absolute fact, what meaning the spirituality can have?

Whether it is something except that this term often involves ambiguous ambition for the meaning and experience of subjective facts, and instead of the subjective facts, a set of psychological affairs is considered, due to the ignorance of the fact that the soul (spirit) and that spiritual dimension of human existence is transfigured according to specific principles and only within the great traditions that have a celestial origin (Nasr, 1999: 77).

When the principles of these traditions are ignored or denied, and spirituality and spiritual affairs also lose their ratio-
1 In Hinduism, the person's soul which is the origin of all human acts.
2 In Hinduism, the illusion or appearance of the phenomenal world.
3 In Buddhism, a transcendent state (soul)
4 The cycle of death and rebirth to which life in the material world is bound. 
nality and sacredness, then the complexities of the material world are confused with the heavenly facts, and the type of spirituality that comes from this confusion is sometimes an ambiguous method that can incorporate everything including emotional affairs, such that in the naturalistic approach we can see such an attitude in subjects related to the meaning of life.

\section{ANALYSIS}

Spirituality and spiritual search of man have been manifested in various forms throughout history, and there are many different spiritual schools, and even within a religious tradition these diversities that are manifested in different cultural forms or in various religious ideals are seen. Spirituality is not an idea or concept, but is an action found throughout human history and is full of the human desire for endurance, eternity, immortality, peace, happiness, prosperity and tranquility, and it is possible to say that in fact, the embodiment of these components is spirituality that has always been and also is the concern of humanity at all times. But in a general classification, this action can be divided into two categories; in one approach, spirituality is meant in relation to the absolute reality and the transcendental matter, that is, a form of encountering with universe and the transcendental reality, which its result is that the unfavorable states such as sorrow, grief, meaninglessness and hopelessness do not appear in human life, or if appear, this way of encountering causes inner satisfaction and, in fact, it can be said that the result of spirituality is the same inner satisfaction (Malekian, 2000: 6). It seems that the best way to reach the spiritual level in this sense is to transcend the tradition and religion, and the way to salvation and to achieve it is to feel the calm and the inner certainty only through the practice of religious teachings. In this approach, the tradition is the realities or principles that are of divine origin and have been revealed to human beings through the characters known as apostles and prophets. Such spirituality is the result of religiosity, and the religiosity is the result of respect to the religious teachings revealed from the heaven to give the meaning to human life. And as previously stated, religion in its original sense is the same principles that have been inspired by God, and it connects human to the main source. This traditional spirituality is a relation and presence with the sacred fact; this spirituality is achieved by the tradition and is the equivalent of the eternal wisdom (wisdom prinnal) which has been deployed in every religion. The eternal wisdom (sophia perennis) is generally considered as the metaphysical reality which is of no initiation and is present in all manifestations and teachings of wisdom. This wisdom is not a matter of the kind of wisdom and thought of the mind. In this wisdom, the problem is that there are truths which are inherent in the human soul, but they are hidden and buried in the depth of the heart (soul), and only those can reach them that are meditative and spiritual (Schuon, 2002: 223-224).From this perspective, spirituality is "a set of universal truths" (universa truthus).

Religion originally means bonding or linking. The reli- gion connects human beings with each other and with God as a sacred religion; and the religion is the origin and source of manifestation of certain principles. Within this approach, there are other views in which attention to absolute reality is considered as a fundamental principle, but the use of religion as a trusted and confident way in them is not established. Of these views, we can refer to some super-naturalistic views in the context of the meaning of life; for example, in this view one can refer to Aristotle's theory of prosperity; the view that happiness is merely achieved through thinking on matters worthy of thought.

\section{CONCLUSION}

The purpose of this article is the philosophical-psychological recognition of the concept of spirituality in English and Persian literature, in this way, by clarifying the concept of spirituality, the way to agree on the recognition of this concept is to prevent many of the problems caused by conceptual ambiguity in this issue and pave the way for further research in other disciplines of the humanities on this issue.

According to what was said, it can be concluded that since the existence of a divine doctrine is necessary for human life, ${ }^{5}$ the valid spirituality is also ultimately achieved for human by relying in celestial religion and breathing in an institutionalized religious environment in which the existence of the absolute transcendent fact and practicing a set of principles with a firm support is one of the decisive and fundamental principles.

But in another approach to the issue of spirituality, the lack of attention to absolute reality is observed. In other words, basically, the absolute reality in this approach is not meaningful, but merely the consideration of the psychological and emotional state of individuals in achieving spirituality, or the sense of tranquility and going beyond the limitations that humans have always sought are matter.

Although human beings, in their search for access to components mattered in spirituality, such as peace, hope, meaningfulness, purposefulness, pleasure, and so on, are encountered with the absolute fact and consider it as an appropriate tool for achieving their goals, but firstly, this issue is rare; and secondly, here the application of the absolute fact for a person is solely in terms of its psychological and anthropological outcomes. Naturally, such an approach to absolute reality allows humans to put it aside, if for any reason, they consider this absolute reality as an obstacle to achieve their goals. Since, here, they do not believe in absolute reality, this action will be permitted. In such an approach, human is merely seeking a kind of meaning, and then naturally seeking peace, liberation from suffering, joy and happiness.

$5 \quad$ To study about the necessity of sending the prophets and the need for religion, see: Allameh Helli, Kashf al-Muradfi Sharh-i al-E'ateghad (correction and addition of Hassan Hassanzadeh Amoli (Qom, Al-Nashr al-Islami Institute, 1992); Al-Tabiat al-Rabe'ah fi Hosn-i al-Ba'tha va fial-Vejub-i al-Ba'tha, pp. 346-348. 


\section{REFERENCES}

Alavi, S.A.R. (1996). Masnavi Dictionary. Tehran: Mah Publication.

Amid, H. (1997). Amid Dictionary. Tehran: Sepehr Publication, $10^{\text {th }} \mathrm{ed}$.

Beheshti, M. (n.d). Saba Persian Dictionary. Tehran: Saba Publication, $6^{\text {th }}$ ed.

Bossley Woolf, H. (n.d.). Webster's New Collegiate Dictionary. Merriam Company, Springfield, Massachusetts, U.S.A.

Brand, H., \& Joachim, H. (2004). The Encyclopedia of Protestantism.Vol.4, London Rotledge.

Bride, W., Sherwood, W., \& Elizabth, J. (1963). Columbia Encyclopedia. New York and London Columbia University press.

Clarend on press Oxford the new short Oxford English Dictionary on historical principles. (1993). Vol. 2., New York: Oxford university press.

Daei al-Islam, S.M. (1985). Nezam Dictionary. vol. 5, Tehran: Heidari Publication, $2^{\text {nd }}$ ed.

Deh Khoda, A.A. (1973). Dehkhoda Dictionary. Vol. 25, Tehran: Tehran University Press.

Edward A. (1907). "Spiritualism” in catholic Encyclopedia. NewYork: the Encyclopedia press Inc.

Eliade, M. (1981). Encyclopedia of Religion. Vol.13, New York: Macmillan publishing and collier Macmillan publishers.

Griffin, D.R. (2002). God and religion in the postmodern world (Translated by Hamid Reza Ayatollahi). Tehran: Aftab-i Tawse'ah publication.

Hasting, J. (n.d.). Encyclopedia of Religion and Ethics. Vol. 11, New York: Charles Seribner's sons.

Helli, A. (1992). Kashf al-Muradfi Sharh-i al-E'ateghad (correction and addition of Hassan Hassanzadeh Amoli). Qom: Al-Nashr al-Islami Institute;

Hinliss, J. (2003). Spirituality (translated by A. Rastgar). Haft Asman Journal, issue 5, Winter, (pp 67-75)

Ibrahimi Dinani Gh.H., (2003). Rationality and spirituality in Islam. Haft Asman Journal, 20(5), Autumn, (pp9-13)

Khodaparasti, F. (1997). A comprehensive dictionary of Persian synonyms and antonyms. Shiraz: Danesh-Nameh Farsi Publication.

King U., (2004). Spirituality (Translated by Alireza Shojaee Zand), Haft Asman Journal, 23(6), Fall, (pp73-94)

Maher, M., \& Bolland, J. (1907). Spirit in Catholic Encyclopedia. Vol. 14, New York: the Encyclopedia press Inc.

Malekian, M. (2000). Rationality and religion. Naw-Andishi Nameh

Malekian M., (2000). Spirituality and affection are the essences of all religions. Journal of Baztab-i Andisheh, Issue 9, (pp7-12)

Mawlavi (Mohammad Balkhi), J. M. (1996). Masnavi Ma'navi (corrected by Ghavam al-Din Khoramshahi). vol. 1, Tehran: Nahid publication.
McCormick, D. (2004). Spirituality and Management (Translated by Ali Rastegar). Haft Asman Journal, 22(6),(pp179-192)

Ian I. Mitroff and Elizabeth A. Denton. (2000). A study of spirituality in the workplace: www.workplacespirituality.com

Movahed M.A., (1995). God and the meaning. Journal of Kian, 44(7), (pp6-9)

Nafisi (Nazem al-Ateba), A.A. (1939). Nafisi dictionary. vol. 5, n.p: Khaiam.

Najafi, A.H. (1999). Persian Colloquial Dictionary. Tehran: Niloufar Publication.

Nasr S.H., (1999). Spirituality and the science: Convergence or divergence? (Translated by Forouzan Rasekhi). Review and Ideas; Vols. 19\&20 (5), Summer \& Autumn, (pp 23-40)

New Catholic Encyclopedia. (2003). Detritor; Catholic University of America; ${ }^{\text {nd }}$ ed., Washington.D.C: Thomson/ Gale

Partou, A.Q. (1998). Vajeh-Yab Dictionary (The Persian equivalents for foreign words). vol. 3, n.p: Asatir publishing, $2^{\text {nd }} \mathrm{ed}$.

Ragan W., (2000). Religion sacred and spirituality definitions. www.danann.org.

Rampouri, Gh.D. (1996). Ghiyas al-Loghat. Tehran: Amir Kabir Publication.

Schlodark, Ph. (2001). Spirituality and Theology (Translated by Hassan Ghanbari). Haft Asman Journal, Issues 9\&10, vol. 3, Spring and Summer,(pp32-49)

Schuon, F. (1992). Images of primordial \& mystic beauty (Translated by Hossein Khandagh Abadi), edited by Behzad Saleki.

Schuon, F. (2002). The eternal wisdom (translated by Mustafa Malekian). A journey to sphere of soul (pp. 223-224). Tehran: Negah-i Mo'aser publication,

Spohn W.C., (n.d.). Spirituality and ethics: Exploring the connection.www.Relg-studies.scuedu

The American Heritage Dictionary of English Language. (2003). Edited by Lesley Brown.

The Encyclopedia of world book. (1960). Chicago: Field Enterprises Educational corporation.

The Heritage Illustrated Dictionary of the English Language. (n.d.). Boston: Ammerican Heritage Publishing Co. and Houghton, Mifflin Company.

Troll C.W., (1995). Present and Future Catholic Spirituality (Translated by Mehrdad Vahdati). Daneshmand: Review and Idea, $3^{\text {rd }}$ and $4^{\text {th }}$ Issues, vol. 1, Summer and Fall, (pp165-180)

Wickfield G.S., (2002). Spirituality and worship (Translated by Mohammad Hassan Mohammadi Mozaffar). Haft Asman Journal, Issue 4, vol. 16, Winter, (pp63-92)

www.dictionary.com: Word net 2.0. (2003). Princeton university

www.DUMMIES.com: Exploring the meaning of spirituality www.helpyourself.com: Spirituality 